\title{
MŐCSÉNYI-SZOBOR AVATÁSA A BUDAI CAMPUSON
}

HTTPS:/IDOI.ORG/ $10.36249 / 53.12$

A Mőcsényi Mihály Centenáriumi Év keretében 2019. november 8-án avatta fel a Tájépítészeti és Településtervezési Kar Professzor úr szobrát a Budai Arborétum felsőkertjében, a szoborkertben. A szobor Dinyés László szobrászművész alkotása. Szoboravató, megemlékező beszédet mondott Füleky Zsolt, a Miniszterelnökség Építészeti és Építésügyi helyettes államtitkára, Dr. László Imre, Budapest XI. kerület Újbuda polgármestere és Palkovics László, az egyetem rektora. A szoboravató ünnepségre Mőcsényi professzor tisztelői, barátai, tanítványai, kollégái nagy számban jöttek el.

A Kar nevében ezúton mondunk köszönetet a szoborkert méltó kialakításáért a Kar oktatóinak, az alapszakos tájépítőmérnök-hallgatóknak, a Dísznövénytermesztési Tanszéknek, a Garten Kft-nek-és a FŐKERT-nek. A szoborállítás költségeit az Ormos Imre Alapítvány közreműködésével a tájépítészek közössége, Mőcsényi professzor tisztelői, kollégái, barátai támogatásai fedezték.

Köszönet illeti a Mőcsényi-emlékév támogatóit: Land-A Kft., Balatongyörök
Önkormányzat, Baraczka Katalin, Borkó Károly, Boromisza Zsombor, Dr. Csemez Attila, Gellér Zita, Geometria Kft. Tenke Tibor, Gerzánics Annamária, Garten Stúdió Kft., Geum Müterem Tájépítész Kft., Hajdu-Nagy Gergely, Hubayné Horváth Nóra, Kiselbach Tamás, Maurer-Klimes Ákos, Lakatos Miklós, Lépték-terv Kft. - Szakács Barnabás, Magyar Kertépítő Kft. - Szántó Csaba, Móricz Anna, Pagony Kft. - Herczeg Ágnes, Panda Pont Mérnöki Iroda Kft., Sárospataki Máté, S-TÉR - Sándor Tamás, s73 Tervezőiroda, Szabadics Anita, Dr. Szikra Éva, Szilágyi Kinga, Szommer Júlia, Torma Sarolta, Táj-consult Bt., Tér Team Kft. - Szabó Gábor.

Fekete Albert

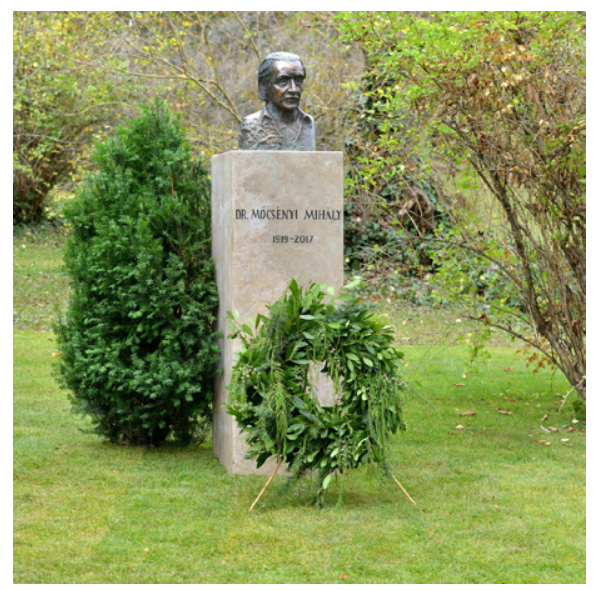

\section{1. ábra/fig.:}

Mőcsényi professzor szobra a Budai Arborétum szoborkertjében (FOTó: GLÁZER ATTILA) 